\title{
CST2 Gene
}

National Cancer Institute

\section{Source}

National Cancer Institute. CST2 Gene. NCI Thesaurus. Code C159788.

This gene plays a role in cysteine proteinase inhibition in submandibular and sublingual saliva. 